\title{
The influence of corporate market power on health: exploring the structure-conduct- performance model from a public health perspective
}

\author{
Benjamin Wood ${ }^{1 *}$ (D, Owain Williams², Phil Baker ${ }^{3}$, Vijaya Nagarajan ${ }^{4}$ and Gary Sacks ${ }^{1}$
}

\begin{abstract}
Background: The detrimental impact of dominant corporations active in health-harming commodity industries is well recognised. However, to date, existing analyses of the ways in which corporations influence health have paid limited attention to corporate market power. Accordingly, the public health implications of concentrated market structures, the use of anti-competitive market strategies, and the ways in which market power mediates the allocation and distribution of resources via market systems, remain relatively unexplored. To address this gap, this paper aimed to identify and explore key literature that could inform a comprehensive framework to examine corporate market power from a public health perspective. The ultra-processed food (UPF) industry was used to provide illustrative examples.
\end{abstract}

Methods: A scoping review of a diverse range of literature, including Industrial Organization, welfare economics, global political economy and antitrust policy, was conducted to identify important concepts and metrics that could be drawn upon within the field of public health to understand and explore market power. The Structure-ConductPerformance (SCP) model, a guiding principle of antitrust policy and the regulation of market power, was used as an organising framework.

Results: We described each of the components of the traditional SCP model and how they have historically been used to assess market power through examining the interrelations between the structure of industries and markets, the conduct of dominant firms, and the overall ability of markets and firms to efficiently allocate and distribute the scarce resources.

Conclusion: We argue that the SCP model is well-placed to broaden public health research into the ways in which corporations influence health. In addition, the development of a comprehensive framework based on the key findings of this paper could help the public health community to better engage with a set of policy and regulatory tools that have the potential to curb the concentration of corporate power for the betterment of population health.

Keywords: Market power, Corporate power, Industry structure, Firm conduct, Market failure, Antitrust policy

\footnotetext{
* Correspondence: bmwood@deakin.edu.au

${ }^{1}$ Global Obesity Centre, Deakin University, Geelong, Australia

Full list of author information is available at the end of the article
}

(c) The Author(s). 2021 Open Access This article is licensed under a Creative Commons Attribution 4.0 International License, which permits use, sharing, adaptation, distribution and reproduction in any medium or format, as long as you give appropriate credit to the original author(s) and the source, provide a link to the Creative Commons licence, and indicate if changes were made. The images or other third party material in this article are included in the article's Creative Commons licence, unless indicated otherwise in a credit line to the material. If material is not included in the article's Creative Commons licence and your intended use is not permitted by statutory regulation or exceeds the permitted use, you will need to obtain permission directly from the copyright holder. To view a copy of this licence, visit http://creativecommons.org/licenses/by/4.0/ The Creative Commons Public Domain Dedication waiver (http://creativecommons.org/publicdomain/zero/1.0/) applies to the data made available in this article, unless otherwise stated in a credit line to the data. 


\section{Background}

The public health community has for decades identified the risks associated with the strategies and practices used by corporations that profit from health-harming commodities [1-7]. Recently, public health scholars in the emerging field of the corporate and commercial determinants of health $(\mathrm{CDoH})$ have called for increased scrutiny of the power of corporations active in healthharming industries and its influence on population health [8-12]. Indeed, it is extensive power that confers corporations with the ability to shape many different aspects of society. Corporate power is present in sociopolitical aspects such as policy-making processes; in the supply chains and retail environments that structure product affordability, accessibility and availability; and in the consumption habits of individuals around the world [13]. To date, however, the public health literature has mainly explored corporate power in terms of its impact on population health via its political, regulatory and governance influence [14]. While analyses that focus on how corporations influence policies and regulations are undoubtedly important, we argue that insufficient attention has been devoted to understanding and examining the market power of corporations as a determinant of health, and indeed as a key explanation and source of corporate political power.

In market economies, the market system is the institutional context wherein most economic activities, notably the allocation of resources and profit accumulation, are coordinated [15-17]. Understanding who gets what and why, and at what cost, as mediated by market systems requires an understanding of market power [18]. Market power, like the concept of power in general, is a contested subject. In this paper, we draw upon Stiglitz' (2017) description of market power as the ability of firms to engender anti-competitive market conditions through conduct that prevents, lessens or distorts the structure and process of competition [19]. The primary goal of shaping competition can be understood as creating anti-competitive market conditions conducive to generating sustained profit margins over what would otherwise be possible in a truly competitive market $[19,20]$. This, in turn, can grant the ability to accumulate substantial wealth and resources over a sustained period of time, and precedes and reinforces the expression of political power by corporations. Indeed, the ability to influence politics and policy generally requires the accumulation and effective deployment of large amounts of money and other material resources [21, 22].

We argue that the omission of market power from public health analyses has led to a number of key disciplinary blind spots. First, minimal acknowledgement has been given to examining and understanding important market structure characteristics that confer firms with structural power vis-à-vis consumers, buyers, suppliers, small rival firms, and, in some cases, governments. Monopolistic/oligopolistic (i.e. market structures with only one or a small number of firms) and monopsonistic/oligopsonistic (i.e. a market dominated by only one or a small number of purchasers of given goods) market structures are of particular concern given that they often provide leading firms with both the ability to control the production, marketing and distribution of products in the value chains in which they operate, as well as the power to generate profits at the expense of other market stakeholders, including consumers and suppliers $[19,23]$. Indeed, the majority of health-harming industries are oligopolistic in nature (and, in some cases, oligopsonistic), which has important ramifications for efforts to curb the consumption of the products they produce, market, and sell [23, 24]. Furthermore, concentrated markets often confer dominant firms with considerable structural and relational power relative to governments, not least through their ability to control large amounts of capital and labour. This structural and relational power can increase government hesitancy to implement policies and regulations that could threaten the profit-making abilities of these dominant firms, as well as the wider stability and health of national economies $[25,26]$.

Second, limited public health attention has been given to analysing the allocation and distribution of resources, generated wealth and incurred costs via the market systems of key health-harming industries [27]. The presence of considerable market power in private markets can lead to the inefficient allocation and distribution of resources, wealth, and costs - this constituting a key component of what is commonly referred to as 'market failure' [28]. Concentrated market power can also be harnessed to influence democratic political processes, leading to situations - such as when government policy makers and regulatory bodies are co-opted to serve private interests instead of public interests - in which many of the social and ecological costs associated with business activities (i.e. negative externalities) are not addressed [29, 30]. Accordingly, from a public health perspective, market power analyses can inform an examination into how much profit a health-harming corporation generates; how much of this accumulated capital is subsequently allocated to corporate strategies known to undermine public health; and how the generated wealth and incurred costs (including externalised costs) from market transactions are distributed among corporations, society at large, and the environment.

Finally, market power analysis is well-placed to help the public health community engage with a broader set of government policy levers that could promote and 
protect public health through addressing concentrated market power and related instances of market failure $[31,32]$. Pertinent examples include policy regimes (e.g. antitrust policy, trade and investment policies, industrial policy) that (in principle) directly address concentrated market power, as well as fiscal policy regimes intended to redistribute the economic burden of externalised costs from the public towards the corporations responsible for driving the costs.

Given the aforementioned blind spots and opportunities, the aim of this study was to identify and explore key literature that could inform the development of a comprehensive framework to examine corporate market power from a public health perspective. We focused on the ultra-processed food (UPF) industry (refer to Supplementary File 1 for a definition) to provide illustrative examples. The UPF industry was selected for two main reasons: i) the UPF industry is a key industry of public health concern, given that diets characterised by high UPF consumption have been linked with a range of adverse population health outcomes, including all-cause mortality [2, 3, 33-55]; and ii) the markets of the UPF industry are markedly heterogeneous across both product and geographic boundaries, and therefore the industry is well-placed to highlight the importance of a comprehensive approach to examine market power [56, 57].

\section{Methods}

\section{Literature review}

A scoping review of a range of literature was performed to identify relevant concepts and approaches to identify and monitor corporate market power. The initial search strategy involved a review of scholarly articles, books and other relevant documents in public health, business, economic, political economy, and antitrust policy literature. These were sourced from Scopus, Web of Science, Medline, Business Source Complete, ABI Inform, Passport, Thomas Reuters Westlaw and Lexis Advance databases. The key search terms used were market power, monopoly/oligopoly power, monopsony/oligopsony power, and market failure. The initial search was supplemented by snowball searching in order to find further documents in the academic and grey literature. We did not set any date limits for the search. We included documents that were published in English and that presented market power concepts and approaches in accordance with the analytical framework (discussed below) that we thought could inform an examination of market power from a public health perspective. In addition, we included documents that described potential areas of government policy for countering corporate market power. Where relevant, we identified illustrative examples of market power with regard to the UPF industry.

\section{Analytical framework}

We used the Structure-Conduct-Performance (SCP) model as an organising framework for our analysis (see Fig. 1) [58].

The SCP model was first described by Edward Mason and Joe Bain in the 1930s, and later popularised by Bain in the 1950s, as part of a broader agenda to identify and address both the market power and political power of firms active in concentrated markets through government policy, particularly antitrust policy [19, 59-62]. Since its introduction, it has been very influential in Industrial Organization and antitrust scholarship, fields that have traditionally concerned themselves with the structure and functioning of industries and their markets [63]. The traditional SCP approach posited that it was industry structure (i.e. the number and concentration of firms active in a given market) that determines firm conduct (i.e. firm strategy and behaviour) within the industry. In turn, firm conduct was seen to determine industry performance (i.e. the efficiency of an industry in using, allocating and distributing resources, as well as its degree of innovation) $[60,63,64]$. Given its deterministic nature, the analytical and methodological centrepiece of the traditional SCP approach was the analysis of industry structure, with a major emphasis on the use of sectoral or market concentration indices [63]. Accordingly, a central argument made by traditional SCP scholars was that the government should intervene to regulate concentrated markets, positing that doing so would prevent anti-competitive firm conduct from occurring, thereby averting the inefficient allocation of resources [58].

Detractors of this structuralist approach were critical of its deterministic nature, arguing that firm conduct (e.g. the pursuit of mergers and acquisitions) could also shape industry structure, and that firm performance shapes firm conduct (e.g. firms with substantial accumulated earnings can deliberately incur short-term losses to

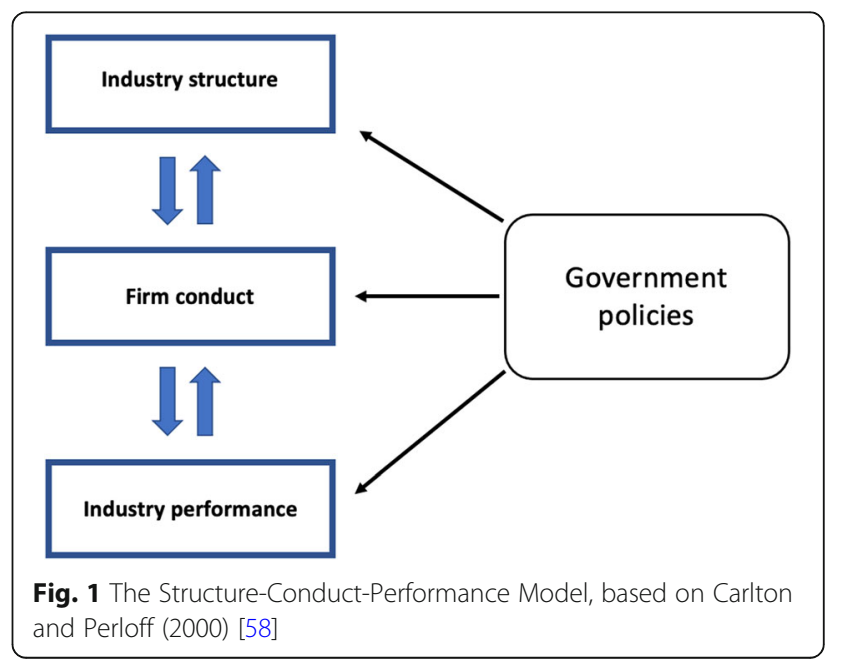


drive out competitors, or innovative firms could leap frog market leaders) [65]. New approaches were proposed, including those by the New Empirical Industrial Organization scholars, which placed greater emphasis on exploring profits (i.e. the financial gain realised by a firm when earnings exceed the total amount of expenditure) and price mark-ups (i.e. the difference between the cost of a good and service and its total cost of production) to analyse the extent of market power [66]. However, these new approaches also faced criticism due to their methodological and empirical challenges and limitations. As a pertinent example, the data required to accurately calculate price mark-ups are often very difficult, if not impossible, for researchers to obtain in the absence of insider information [20,65]. Today, a number of antitrust (competition) authorities around the world instead draw from an adapted SCP model (as represented in Fig. 1), in which the relationships between each of the components are not assumed to be one directional and deterministic, and where market interventions by the government can potentially target all three components [58, 67-69]. We used this adapted model to frame our analysis.

\section{Data synthesis}

The data extracted from the literature were coded and grouped according to the three interlinked components of the SCP model: industry structure, firm conduct, and industry and firm performance. Within each component, key concepts and related metrics for analysis of corporate power from a public health perspective were identified and discussed. A detailed description of these metrics is provided in Supplementary File 2. A glossary of key market power-related terms and definitions are provided in Table 1.

\section{Results}

The structure of an industry and its markets

An assessment of industry and market structure is a crucial step in exploring the market power of firms, and there are a number of metrics that can be used to help

Table 1 A glossary of key terms and definitions related to market power

\begin{tabular}{|c|c|}
\hline Allocative efficiency & The allocation of society's limited resources to their most valuable use \\
\hline Barriers to entry (market) & Market-based structural factors that impede or prevent a new firm from entering a market \\
\hline $\begin{array}{l}\text { Brand/product } \\
\text { differentiation }\end{array}$ & The ability of a firm to differentiate its brands/products from those of its rivals \\
\hline $\begin{array}{l}\text { Common shareholder } \\
\text { ownership }\end{array}$ & $\begin{array}{l}\text { The situation that arises when investors, usually institutional investors, own shares in a number of firms active in the } \\
\text { same market }\end{array}$ \\
\hline Distributive efficiency & $\begin{array}{l}\text { The distribution of costs (including externalised costs) and benefits generated from market transactions in the fairest and } \\
\text { most just manner }\end{array}$ \\
\hline Dynamic efficiency & $\begin{array}{l}\text { The ongoing development of both process innovations (e.g. improvements in organisational, production or delivery } \\
\text { methods that reduce cost or increase quality) and product innovations (i.e. new product and packaging development) } \\
\text { that provide benefits to both the firm and society at large }\end{array}$ \\
\hline Gross profit margin & The difference between the total sales revenue and the total cost of production \\
\hline Industry & A group of establishments that are engaged in the same or similar kinds of production activity \\
\hline Intangible assets & An asset, such as a brand or trademark, that does not have a physical or financial embodiment \\
\hline Market & A market is the product and geographic space in which rivalry and competition take place \\
\hline Market capitalisation & The discounting of a corporation's expected, risk-adjusted future profit and interest payments to their present value \\
\hline Market failure & The situation defined by an inefficient allocation and distribution of resources, wealth and costs in a market system. \\
\hline Market strategy & $\begin{array}{l}\text { A concerted pattern of actions taken in the market environment for the purpose of improving corporate performance } \\
\text { (i.e. maximising profits and shareholder returns) }\end{array}$ \\
\hline Monopoly & A market structure in which only one firm sells a particular commodity \\
\hline Monopsony & A market structure in which there is only one firm that buys goods and services offered by many suppliers \\
\hline Non-market strategy & $\begin{array}{l}\text { A set of actions designed to improve or protect overall corporate performance by influencing the interconnected policy, } \\
\text { regulatory, institutional, ideological and broader socio-political structures that shape market environments }\end{array}$ \\
\hline Oligopoly & A market structure in which only a few firms sell a particular commodity \\
\hline Oligopsony & A market structure in which there are only a few firms that buys goods and services offered by many suppliers \\
\hline Productive efficiency & The production of products or services at the lowest possible cost \\
\hline Share repurchase & The practice of a firm buying back its own shares \\
\hline Transfer pricing & $\begin{array}{l}\text { The manipulation of pricing and payments for intermediate outputs, brand names and patent use between subsidiaries } \\
\text { in order to maximise profits in low-tax jurisdictions }\end{array}$ \\
\hline Vertical integration & The extent to which a firm owns or controls its suppliers, distributors or buyers \\
\hline
\end{tabular}


identify and determine the extent of structural market power that certain firms hold $[60,64,67,70]$.

\section{Market concentration}

For decades, market concentration has been central to market structure analysis [60, 71, 72]. Highly concentrated markets, often understood as both a symptom and cause of market power, have long been recognised to confer dominant firms with a considerable structural advantage over other market-based actors, including consumers, suppliers, and new market entrants [60, 7173]. The two most common metrics to measure market concentration are the Herfindahl-Hirschman Index (HHI) and the four-firm concentration ratio (CR4) [74]. The HHI, calculated by first squaring the market shares (as percentages) of all active firms in the market and then summing all of these together, is the main market concentration metric used by competition authorities today [75]. The higher the calculated value (maximum of 10,000), the greater the concentration of the market. The European Central Bank (and the United States Department of Justice prior to 2010) considers markets with a HHI value of greater than 1800 to be highly concentrated; between 1000 and 1800 to be moderately concentrated; and less than 1000 to be of a low concentration $[76,77]$.

In comparison, the CR4 - the most relevant concentration metric prior to the development of the $\mathrm{HHI}-$ is calculated by summing the market shares of the largest four firms in the market. A market with a CR4 of greater than 60 is often considered to be a concentrated market; whereas a market with a CR4 of less than 40 is often considered to be competitive [74, 78]. In most cases, the $\mathrm{HHI}$ is generally preferred to the CR4 because, unlike the CR4, the HHI takes into account all firms active in the market, as well as large variations in the market shares of the top firms [74]. As an illustration, consider two hypothetical markets, Market A and Market B. In Market A, the top four firms have market shares of 65 , 10,3 , and $2 \%$, respectively. In Market B, the top four firms all have market shares of $20 \%$. Let us also assume that the remaining share of both markets is evenly spread among a large number of firms, meaning that their market shares are minimal and therefore do no impact our calculations. The CR4s of both Market A and Market B would be 80 (highly concentrated), despite their markedly different market structures. In comparison, the HHI of Market A would be close to 4338 (very highly concentrated) whereas the $\mathrm{HHI}$ of market $\mathrm{B}$ would only be around 1600 (moderately concentrated). In this case, the large difference between $\mathrm{HHI}$ values is due to the fact that Market A, unlike Market B, is dominated by only one firm.
A major challenge of measuring market concentration is being able to accurately define the product and geographic boundaries of the market in question $[79,80]$. In this respect, it is important to point out that although the terms 'industry' and 'market' are often used interchangeably, they are not the same concepts. According to the Organisation of Economic Co-operation and Development (OECD), industry is loosely defined as a group of establishments that are engaged in the same or similar kinds of production activity [81]. A market, in comparison, is the product and geographic space in which rivalry and competition take place [82]. The UPF industry, as an example, can be described as a group of firms engaged in the production of UPFs. A number of different product markets exist within this industry because competition does not take place between all UPF product types, nor does it occur across all geographic boundaries. For instance, at the consumer level, breakfast cereal manufacturers are not in direct competition with soft drink manufacturers; therefore, we can assume that these are separate markets of the UPF industry. Likewise, a firm that only sells breakfast cereals in China is not in direct competition with a firm that only sells breakfast cereals in Western Europe. Table 2 provides an illustration of the differences in $\mathrm{HHI}$ values according to how market boundaries are defined.

As can be seen in the Table 2, one of the potential risks in defining the product and geographic boundaries of UPF markets too broadly is that the calculated market concentration values may underestimate the true concentration of the market in question. For instance, if we calculated the market concentration of the entire global UPF market, we could be misled into thinking that the market is competitive (because of the apparent low concentration). In reality, however, the global UPF market is

Table 2 An illustration of the variation in Herfindahl-Hirschman Index $(\mathrm{HHI})$ values within the ultra-processed food industry according to the defined product and geographic boundaries of the market

\begin{tabular}{lll}
\hline & Soft drink market & Carbonated soft drink market \\
\hline Global & 586 & 2661 \\
Western Europe & 562 & 2932 \\
United Kingdom & 818 & 3493 \\
\hline
\end{tabular}

Note: $\mathrm{HHI}$ values $>2500=$ very high concentration; $1800-2499=$ high concentration; 1000-1799 = moderate concentration; $<999=$ low concentration. Thresholds based on adapted European Central Bank and historical US Department of Justice Thresholds [76, 77]

Source: Passport. Market share data based on 2019 off-trade sales data. Product market boundaries based on Passport's categorisation of soft drink products. The soft drink market includes carbonated soft drinks, juice, concentrates, ready-to-drink tea, ready-to-drink coffee, energy drinks, sports drinks, Asian specialty drinks, and bottled water. Carbonated soft drinks include cola carbonates and non-cola carbonates (e.g. lemonade, ginger ale) 
made up of many different, albeit often interconnected, oligopolistic and oligopsonistic market structures (this is often captured in the economic literature by the somewhat oxymoronic term monopolistic competition) $[23,83]$. Indeed, in many cases, dominant global corporations are located at the apex of a patchwork pyramid of product and geographic markets in which their market power is variable, but nonetheless typically concentrated in the majority of their key markets. Therefore, the structural market power of a global firm that operates in a number of UPF markets across different product and geographic dimensions is best explored by considering the firm's presence in each of the markets in which it operates - across both product and sometimes segmented market-geographic dimensions - rather than by simply assessing its share of the entire global market.

\section{Common shareholder ownership and its effect on market structure}

The potential effect of common shareholder ownership on the competitive structure of a market or industry is an important consideration that can be incorporated into market concentration calculations. Common shareholder ownership refers to the situation wherein investors, usually institutional investors, own shares in a number of firms active in the same market [84, 85]. Evidence suggests that common shareholder ownership can be detrimental to competition, especially in highly concentrated markets, due to increased management incentives to either tacitly or explicitly collude with rivals [84, 86-88].

Recent work has highlighted the extent of common ownership across a number of key sectors in the global food value chain, including the UPF manufacturing sector [85]. Five key institutional investors (Blackrock, Vanguard, State Street, Capital Group, and Fidelity) together own between 15 and 25\% of large global food corporations Mondelez, Tyson Foods, Kellogg, PepsiCo, General Mills, The CocaCola Company, and Dr. Pepper [85]. To capture the effect of common shareholder ownership, the modified HHI (MHHI) metric is commonly used [84]. The MHHI, which can be interpreted in the same manner as the HHI, effectively translates the estimated degree of control or influence by common shareholders over firms in the same market into a market concentration value [84]. The MHHI is determined by estimating the anti-competitive effects of common ownership (referred to as the MHHI delta), and then adding this value to the original $\mathrm{HHI}$ value of the market. The steps required to calculate the MHHI delta are detailed elsewhere [89].

\section{Barriers to entry}

An examination of barriers to market entry - anticompetitive practices and structural factors that can impede or prevent a new firm from entering a market is another important component of market structure analysis. The presence of considerable barriers to entry confer incumbent firms with structural market power by reducing the countervailing threat of potential competition [90]. One of the major barriers to entry in many UPF markets is the presence of considerable product and brand differentiation, referring to the ability of a firm to differentiate its products and brands from those of its rivals [23]. As a result of many years of sustained and extensive marketing, large firms that have been active for a long period of time typically have a substantial advantage over new firms in that they are already well-recognised and enjoy a large and loyal consumer base. A case in point is the Coca-Cola Company and its flagship brand Coca-Cola, which, for decades, has been one of the most recognisable brands in the world [91]. Other cost-based market barriers to entry include the productive economies of scale that have been achieved by large and often globalised incumbent firms, as well as their well-established relationships and networks with suppliers, distributors, and large retailers $[23,72,82,90$, 92-98]. Moreover, the nature of the products in many industries, such as the UPF industry, means that there is rarely substantial innovation that would break down established market-based barriers to entry.

\section{Other elements of market structure}

A number of other important market structural elements also warrant examination in market power analysis. For instance, vertical integration - the extent to which a firm owns or controls its suppliers, distributors or buyers - can confer a firm with a considerable structural advantage over its rivals or new market entrants [99]. Additionally, the degree of import penetration (i.e. the extent to which domestic consumption comes from imports), the export share of production (i.e. indicates the importance of foreign markets for a given industry), and the existence and nature of explicit or tacit collusion also affect the competitive structure of an industry [72, 82, 100].

Lastly, the globalisation of production is important in exploring certain structural advantages that firms may have over other competitors, as well as governments [25]. For instance, large firms with subsidiaries in different countries can readily mobilise capital across borders, thereby enabling them to undertake practices designed to minimise tax obligations and maximise financial returns [101-103]. Transfer pricing - the manipulation of pricing and payments for intermediate outputs, brand names and patent use between subsidiaries in order to 
maximise profits in low-tax jurisdictions - is one such example $[104,105]$. A core financing strategy of Nestlé, for instance, has been described as locating its trademarks and patents in Switzerland, its home jurisdiction, in order to set up transnational intra-firm royalty payments designed to repatriate profits in tax-effective ways [102]. Similarly, the US Tax Court recently judged that between 2007 and 2009 The Coca-Cola Co had illegally transferred its profits to low-tax jurisdictions in order to avoid about 9 billion USD in income tax obligations [106].

\section{Firm conduct}

Firm conduct is often understood through the analysis of firm strategy, which is well-placed to explore the ways in which corporate power is exercised and distributed in a variety of interconnected contexts, including market systems [8-11].

\section{Market strategy analysis}

In the business literature, firm strategies are often divided into two components: market strategy and nonmarket strategy [107]. Firm market strategies can be defined as concerted patterns of actions taken in the market environment for the purpose of improving corporate performance (i.e. maximising profits and shareholder returns) [107].

Traditionally, early SCP scholars paid particular attention to the conduct of firms active in highly concentrated markets, such as price gouging and collusion [65]. Later, this structure-centric approach to market strategy was adapted and somewhat inverted by Michael Porter, the founder of modern market strategy, who effectively argued that corporate managers would be well-placed to maintain and increase firm profitability by understanding the competitive structure of their industry [107-109]. Specifically, Porter's five framework - one of most well-known strategic management frameworks - provides a useful analytical framework to understand how dominant firms deploy market strategy to maximise profits over a sustained period of time, largely through achieving and maintaining market dominance (refer to Supplementary File 3 for a brief description of Porter's five forces framework) [108, 109]. Adapting this model to the UPF industry, Wood et al. (2021) describe how dominant UPF corporations use a range of market strategies to maintain market structural advantages over competitors, new market entrants, suppliers, retailers and consumers (e.g. acquire rival firms or new startup companies with promising technologies; raise barriers to entry through extensive brand differentiation and supply chain control strategies; shape retail environments through practices such as exclusive dealing arrangements) [99]. In this respect, the boundaries between firm conduct analysis and market structure analysis are clearly blurred. A key objective of market strategy for dominant firms is to maintain market dominance through shaping the structure of the markets in which they operate. In turn, this can confer dominant firms with an increased ability to influence the behaviour of other market-based actors, thereby further consolidating their market dominance and ability to maximise profits over a sustained period of time. Such a perspective also highlights the somewhat ambiguous nature of differentiating between the deployment of effective market strategies, at least from the firm's perspective, and the potential need for government intervention to address anticompetitive conduct [110].

\section{An integrated approach to corporate strategy}

Markets do not exist in a political vacuum, and firms also deploy a large range of non-market strategies, defined as a set of actions designed to improve or protect overall corporate performance by influencing the interconnected policy, regulatory, institutional, ideological and broader socio-political structures that shape market environments [9, 107, 111-114].

Differentiating market and non-market strategy can be heuristically useful to explore how power imbalances are created or exacerbated in either market or non-market environments. However, in reality, market and nonmarket strategies often work in tandem - captured by the term Integrated Strategy - and, in many circumstances, the distinction between these two components of corporate strategy is artificial [107]. This artificial separation between market and non-market dimensions of corporate strategy is especially apparent and important to recognise in market economies wherein neoliberal-driven structural and ideological changes have further entrenched markets and market thinking into social and political structures, if not as a cultural metaphenomenon [115, 116]. Take, for example, Nestlé's strategy to control marketing channels outside of the conventional market environment (e.g. healthcare facilities) as a means of increasing the revenue it generates from breast milk substitute products [117]. This strategy, well-known to pharmaceutical corporations, effectively entails the incorporation of healthcare actors (e.g. nurses, doctors, midwives and community health workers) into the firm's marketing channels $[117,118]$. As a broader illustration, the corporate social responsibility strategies deployed by large UPF manufacturers are often considered to have both a market-strategy dimension (e.g. by increasing brand value) and a nonmarket strategy dimension (e.g. through gaining political and consumer legitimacy) [119]. 


\section{Market and firm performance}

Examining the performance of an industry entails an assessment of the use, allocation and distribution of resources and wealth that occurs via its markets $[120,121]$. Initially, the performance component of the SCP approach focused on determining the extent to which monopolists and oligopolists misallocated resources through raising prices above the marginal cost of production [65, 122]. From the 1970s onwards, however, the focus of industry and market analysis shifted towards consumer welfare, largely as a consequence of the emerging dominance of the socalled Chicago School with regard to what is now a much diluted antitrust policy, led by prominent scholars such as Judge Bork [120, 123-126]. Bork and his colleagues promoted the idea, which is still widely accepted today, that consumer welfare could best be understood as consumer surplus (i.e. low consumer prices) $[120,123-126]$. This relatively narrow view of consumer welfare has major problems from a public health perspective. First, the idea that low consumer prices are the key signal of the efficiency and effectiveness of the allocative and economic welfare function of private markets means that minimal regard continues to be given to the broader social and ecological outcomes of industry and market activities [127, 128]. Relatedly, and of fundamental importance, the focus on low consumer prices has served to legitimise concentrated corporate power on the grounds that it promotes economic efficiency, both in terms of driving down prices, as well as in creating related efficiencies associated with concentrated market power (we discuss some of these below) [31, 129].

Thus, in light of these considerations, there remains a clear need for the field of public health to outline a broader and more holistic approach to examine industry performance. We argue that this can, at least in part, be achieved by incorporating a broader range of social and ecological considerations into the assessment of economic efficiencies, especially allocative and distributive efficiencies [120, 121].

\section{Market power and allocative (in)efficiency}

Allocative efficiency refers to the allocation of society's limited resources to their most valuable use [69]. Importantly, allocative efficiency can only be achieved if the market in question is fair and competitive (i.e. when all players in a market operate on a level playing field). The presence of considerable market power by one or more firms often results in allocative inefficiency because firms with substantial market power can generate profits - at the expense of consumers and other market stakeholders - in excess of what would be possible in a competitive market environment $[19,130,131]$. In this respect, a key aspect of market power analysis is to examine the financial performance of dominant firms, which in turn can provide insight into the degree of allocative inefficiency of the market in which they operate.

There exist a range of performance-based metrics that, when linked with firm conduct and market structure analyses, can inform an examination of the extent of market power held by a firm. Long term trends of market capitalisation values - defined as the discounting of expected, risk-adjusted future profit and interest payments to their present value - is a pertinent example, and, for publicly listed companies, can be calculated by multiplying the number of shares a firm has by its share price [15]. In the critical political economy literature, market capitalisation has been described as a 'symbolic ritual that converts and reduces qualitatively different power relationships into a singular quantity' [15]. In effect, market capitalisation speaks not just to market power, but more broadly to corporate power, given that the capitalisation process essentially quantifies the social, political and economic influence of a corporation [132].

Related to market capitalisation is the ability of a firm to generate future earnings from its assets and liabilities. In general, the larger the earnings of firm, the greater the capitalisation [15]. Examining the earnings of a firm can complement the assessment of a firm's market capitalisation, and in cases where market capitalisation cannot be determined (e.g. unlisted firms), earnings can instead be used to roughly estimate the ability of a firm to capitalise its differential power relations [15]. A commonly used indicator of corporate earnings is 'Earnings before Interest, Tax, Depreciation and Amortisation' (EBITDA) - a metric that captures a firm's earnings prior to financial and accounting deductions [133]. Similar to market capitalisation, for market power analysis, an examination of a firm's earnings is best conducted over a long period of time (e.g. over 10 years), because firms with substantial accumulated profits can often deploy strategies that incur short term financial losses to drive out rivals (e.g. using predatory pricing) [65].

Gross profit margins, calculated by subtracting the total cost of production from total sales revenue, is another informative firm performance metric for market power analysis [134]. Although gross profit margins are less reliable as an indicator of market power compared to metrics such as the Lerner Index (i.e. (consumer price of a product - marginal cost of a product)/consumer price of a product), the latter requires data that are often not accessible. Gross profit margins tend to be most revealing in cases where the gross profit margins of a firm are considerably higher than its competitors, as well as the industry and sector averages, over a sustained period of time [135]. 
The value of intangible assets owned by a firm should also be considered when identifying and monitoring market power. An intangible asset (e.g. brand loyalty, patents, trademarks) is an asset that does not have a physical or financial embodiment [136]. It has been described that in the current global political economy, power has tended to accumulate into the hands of a limited number of firms that own the majority of intangible assets relative to what exists within the global value chain they operate $[137,138]$. This metric is particularly pertinent for the UPF industry given that brands - aspects of which can be trademarked - play a crucial revenue-generating role for large UPF manufacturers [139-141].

\section{Other forms of allocative inefficiency}

Allocative inefficiency also results from other marketbased failings, all of which are deeply interlinked and perpetuated by market power. A highly important category of allocative inefficiency at the firm level occurs when firms fail to incorporate all of the costs of a product or service into the price set by the relevant market. Externalised costs - commonly referred to as negative externalities - essentially occur when firms are not held financially accountable for the collateral damage they cause to society and the environment $[69,142]$. Although not typically framed in this way, the $\mathrm{CDoH}$ literature contains a vast amount of evidence that describes, and, in some cases, quantifies, a diverse range of social and ecological-related negative externalities generated by a number of health-harming industries, including the UPF industry $[2,32,143$, 144]. Examples include, among many, the substantial global disease burden from diets high in UPFs, as well as the devastating ecological impact of the plastic pollution generated by UPF manufacturers $[2,3,33-55$, 145-147]. Similarly, the $\mathrm{CDoH}$ literature has also explored the ways in which the corporate allocation of money and resources towards certain practices, such as lobbying and intense marketing of unhealthy products, exacerbates the externalisation process $[9$, 11, 27, 148, 149].

Allocative inefficiency also occurs when information relevant to consumer purchasing decisions, as well as other market transactions, is not evenly shared and made readily available. This type of market failure is often referred to as the presence of information asymmetry [130]. There is ample evidence that highlights that information asymmetry is commonplace in UPF markets, where practices such as misleading labelling and the failure to disclose all relevant social (including health) and environmental costs are frequently adopted by large firms $[19,99,130]$.

\section{Distribution of costs and benefits}

All forms of allocative inefficiency in private markets are typically compounded by an unequal distribution of costs (including those externalised) and benefits generated from market transactions [150]. As an illustrative example, the externalised social and ecological costs (e.g. increase in global burden of non-communicable diseases; the adverse ecological impact from plastic pollution) created by the global soft drink industry disproportionately affect particular demographic groups, social classes, and geographies (e.g. young children; lower socioeconomic classes; low- and middle-income countries) [32, 151$160]$. On the other hand, shareholders and corporate executives - groups that tend to be over-represented by a small and privileged elite - largely benefit from the wealth generated from the soft drink industry [19, 161, 162]. Therefore, we argue that an examination of the distribution of incurred costs, as well as the corporate transfer of wealth, should be incorporated into a critical performance analysis from a public health perspective, and more broadly, into an expanded economic concept of consumer or social welfare. Corporate wealth transfer mechanisms that warrant scrutiny include the extent of tax minimisation, the value of dividends paid to shareholders relative to the wealth transferred to other stakeholders (e.g. employees), and the value of shares repurchased by a firm [163]. Share repurchases refer to the practice of a firm buying back its own shares, which has been described as a way of effectively redistributing wealth to shareholders and company executives through the manipulation of share prices and performance metrics (e.g. earnings per share) linked to executive pay compensation $[164,165]$.

\section{Dynamic efficiency}

Dynamic efficiency refers to the development of both process innovations (e.g. improvements in organisational, production or delivery methods that reduce cost or increase quality) and product innovations (i.e. new product and packaging development) that provide benefits to both the firm and society at large [166]. There is conflicting evidence as to whether market power increases or decreases innovation $[167,168]$. In any case, in relation to health-harming industries, product and process innovations that address the negative externalities of pre-existing processes and products should, of course, be welcomed. However, innovations that pretend, or only partly address, pre-existing externalities should be scrutinised, and if appropriate, discredited. It has been described, for instance, that many innovations of the UPF industry adopt nutritional reductionist and greenwashing principles, and thereby fail to provide true social and ecological benefits $[169,170]$. 


\section{Productive efficiency}

Productive efficiency refers to the production of products or services at the lowest possible cost $[121,123]$. In certain situations, such as when firms have achieved economies of scale in production, market power and productive efficiency can have a direct relationship [166]. High levels of productive efficiency of healthharming industries pose a clear problem for public health because, in the majority of markets, the lower the consumer price of a health-harming product, the greater its consumption, and thus, the greater its public health burden. Given the often perverse relationship between lower consumer prices and greater public health costs, the public health community should concern itself with comparing the productive efficiency between healthharming corporations and the organisations that produce healthier and more sustainable product alternatives.

\section{Use of natural resources}

Finally, an assessment of economic efficiencies from both a public and planetary health perspective should also take into account that ecological resources are finite, and that issues pertaining to the scale of resource use cannot simply be reduced to issues of allocation or distribution [150]. Several authors argue that, in many cases, it may not be appropriate for the use of scarce natural resources (e.g. land, water) for business activities, as well as the production of waste and pollution that results from business activities (e.g. carbon emissions, plastic pollution), to be coordinated by the price signals of a market [150, 171, 172]. Instead, it is argued that social decisions that reflect ecological limits need to be made to organise resource use [150]. In this respect, the public and planetary health implications of a firm's relationship with key planetary boundaries (e.g. climate change, freshwater use, land use, biodiversity loss, and chemical pollution), as described by Rockström et al. (2009) and popularised by Raworth's Doughnut Economics model, could be considered as a separate, albeit interlinked, source of economic efficiency [171, 173]. As an example, in certain water-scarce regions of the world, concerns have been raised about the ways in which the bottlers of Coca-Cola Co and PepsiCo's soft drink products have exacerbated the rapid depletion of water sources for surrounding communities [174175].

\section{Towards the development of a framework to examine market power from a public health perspective}

Drawing from our findings, we argue that an expanded SCP model described throughout the results section and depicted below (refer to Fig. 2) could serve as a useful point of departure to inform the development of a comprehensive framework to analyse market power from a public health perspective. Such a framework would be well-placed to explore the ways in which market power mediates, and indeed is mediated by, industry and market structure, firm conduct, and market and firm performance. Moreover, by comprehensively exploring market power through the interconnected analysis of the three components of the SCP model, the public health community could be better equipped to identify and engage with key government policy regimes that could be used to curb concentrated market power.

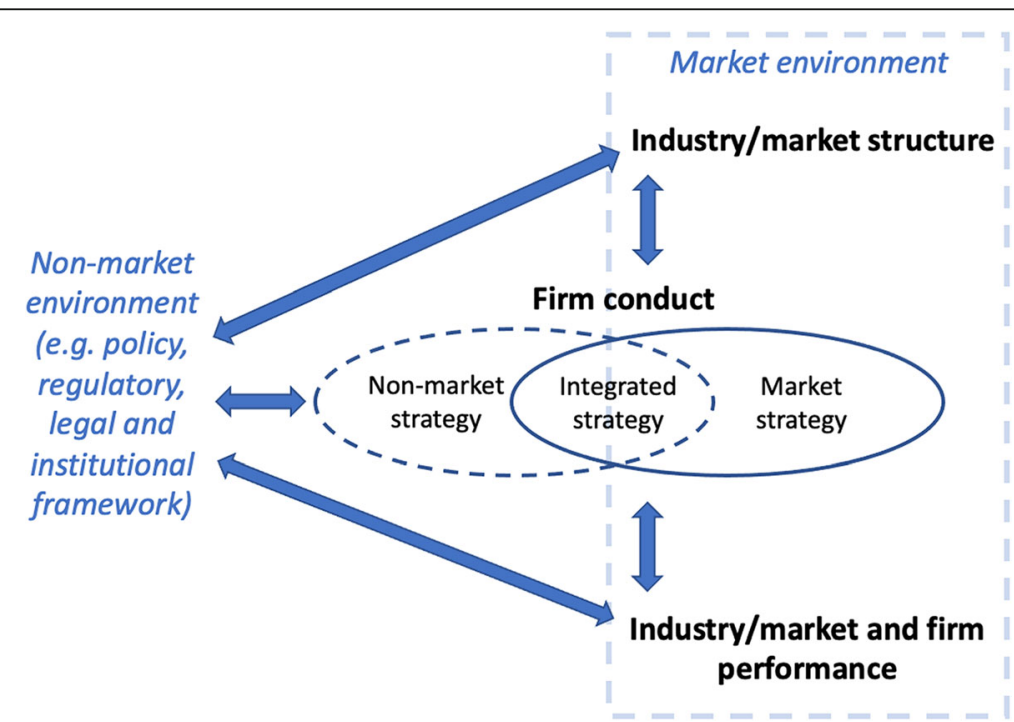

Fig. 2 An adapted SCP model that could be used to inform the development of a comprehensive framework to analyse market power from a public health perspective 


\section{Locating market power within the broader non-market environment}

We recognise that market systems are embedded within the underlying political, legal, cultural, ideological, and technological contexts of capitalist societies, which are systems that markets and capital have historically coproduced [17]. In this respect, market power research needs to be linked with work that explores the existence, use and distribution of corporate power in social and political structures traditionally outside the reach of markets and market thinking [11]. For example, market power analysis could be complemented with an exploration of corporate influence in and on the underlying structures and networks that govern and regulate the rules, processes and norms of the markets in which they operate [176]. Tools for such endeavours include network analysis, and closer monitoring of industry interactions with government bodies, committees, and regulators.

From a theoretical perspective, and in similar fashion to Mikler (2018), we conceputalise corporate market power and corporate political power as a perpetuating unity, rather than as separate entities [177]. Corporate market power can lead to accumulated material resources that can create and reinforce corporate influence in the political environment (i.e. political power), just as corporate political power can both protect (e.g. through regulatory capture) and perpetuate corporate market power (e.g. through shaping corporate-friendly trade and investment agreements) [11]. In addition, the existence, use and distribution of corporate power varies across time and space, and can be fungible across and between markets and jurisdictions. For instance, the increased material power of a firm that results from its power in a specific market can be later deployed to influence the political environment in a different jurisdictional space [11].

\section{Examples of government policy to address concentrated market power}

The proposed framework is well-placed to help explore a number of policy levers that can protect and promote the interests of public health through curbing market power. It is beyond the scope of this paper to review all such relevant policy regimes; instead, we briefly discuss the potential role of a few key examples.

Antitrust policy is a policy regime that, we argue, deserves more attention from public health scholars. Under most current antitrust policy frameworks around the world, the scope for government intervention into markets through antitrust enforcement is limited. As mentioned earlier, this is largely due to the ideological hegemony of the Chicago School's thinking on antitrust policy, wherein concentrated market structures and consolidated market power are justified and legitimised on the grounds of consumer surplus arguments [31, 178]. Historically, however, the primary goals of antitrust policy were to prevent and address the concentration of market power as means of both promoting economic justice and protecting democracy $[19,30,31,61,179]$. Today, the neoBrandeisian anti-monopoly movement (named after Justice Brandeis who served under President Wilson in the early 1900s) seeks to revive the historical goals of antitrust policy, and it is with this movement that public health could aim to engage [180]. Although the main focus of this movement is currently on the big digital technology corporations (in particular, Google, Facebook, Amazon, Apple, and Microsoft), there is likely to be merit in the public health community participating in antitrust policy discussions with reference to addressing (other) health-harming oligopolies that drive the $\mathrm{CDoH}$ [180].

Beyond the way in which the goals of antitrust policy are interpreted today, another important limitation of current antitrust policy regimes around the world is that they are typically bound by their jurisdictional boundaries, and thus, in most cases, fail to operate across geographic boundaries (and more broadly, planetary boundaries) [171, 181]. This is a major issue given the globalised nature of value chains and market transactions, as well as the fact that the social and ecological burden of certain business activities clearly transcend jurisdictional boundaries [171]. In this respect, trade and investment policies could serve as an important lever for addressing the market power of global corporations, especially those that operate in health-harming industries and seek to expand their reach and dominance into new developing markets [19]. A challenge for low- and middle-income countries (LMICs) in particular, however, is that neoliberal global trade, investment and intellectual property regimes often facilitate the globalisation and concentration of market power of firms based in advanced capitalist economies, especially the US and the EU and its members [19]. International trade agreements, for instance, often restrict the ability of LMICs to prevent powerful, health-harming foreign corporations from entering and penetrating their developing national economies [19].

As a final example, industrial policy could also serve as an important policy lever to address the market power of dominant health-harming corporations. Specific to the food sector, industrial policy - that is, government policy that shifts resources from one industry to another - could play a critical role in promoting the economic efficiency of organisations that produce healthier and more sustainable food alternatives to those of UPF manufacturers [182]. Policy actions in this respect could encompass government investment in infrastructure that supports local food supply chains for perishable products 
(e.g. improved transport infrastructure and cold chains); supporting farmers to engage in direct sales in produce markets; increasing support for alternative food business models such as food cooperatives; developing integrated food and agricultural knowledge and innovation systems to address information asymmetries inherent in the food and agricultural value chain; and implementing policies that mandate the public procurement of healthy, local and sustainable food products [183-185].

\section{Discussion}

In this paper we have used the SCP model to identify and describe key concepts and metrics that could inform the future development of a comprehensive framework to analyse corporate market power from a public health perspective. We have provided a number of examples throughout the paper specific to the UPF industry. Building upon the work of scholars who have, for decades, attempted to identify and monitor the presence, use and outcomes of market power, we have described how the SCP model is well-placed to help public health researchers explore the interrelations between the structure of industries, the conduct of dominant firms within these industries, and the overall ability of markets and firms to efficiently allocate and distribute the scarce resources of society. Throughout the paper, we have also suggested how the SCP model could be expanded to take into account a broader range of public health considerations.

While our paper outlines key concepts and metrics to guide market power analysis, it will be necessary to develop a detailed protocol for analysis, including the identification of available data sources, specification of time frames for analysis, and guidance for interpretation of all indicators and metrics. Once developed, such a framework could be adapted to examine market power in different industries of public health concern, such as UPFs, fossil fuels, alcohol, tobacco, and gambling. Regarding the UPF industry, a comprehensive market power framework could be incorporated into the work of existing research networks interested in examining the role of the private sector in shaping and influencing food supply chains and food environments. INFORMAS (International Network for Food and Obesity/non-communicable diseases Research, Monitoring and Action Support) is one such example, and research on market power could be well-placed to help achieve the aims of the network [186]. Given the general concerns about how corporate wealth transfer mechanisms contribute to wealth and social inequality, a comprehensive market power framework could also help inform an exploration of the ways in which market power can exacerbate wealth and social inequalities, especially in market economies [122, 164].
A key strength of this paper is that it links work from economics, business, global political economy and antitrust policy literature with public health. Tackling a complex topic such as market power demands such an interdisciplinary approach. The paper has a number of important limitations. While we have attempted to provide a comprehensive set of concepts and metrics for analysis, we recognise that some of the data required for such analysis is not publicly accessible. While certain data can be collected from publicly available sources such as annual firm reports, national trade databases, and stock exchange websites, access to some of the data (e.g. historical company fundamental data, sales revenue data disaggregated by product and geography) typically requires subscriptions to a number of market and business-related databases. Furthermore, there are currently no standardised benchmarks to guide interpretation of many of the key metrics discussed. In any case, contextual analysis is important and interpretation needs to consider a range of findings. Nevertheless, benchmarks are likely to emerge over time and this could assist future analyses. Finally, a key challenge of the framework described in this paper is that public health practitioners may not have the necessary skills in economics, business, finance and antitrust policy to use and interpret some the proposed metrics. Building these skills should therefore be considered a focus area, particularly for those scholars interested in scrutinising and addressing corporate market power. Fostering collaborations with groups from economics, finance, business and antitrust policy would also help in this regard.

\section{Conclusions}

There is increasing evidence that the unchecked corporate power of dominant firms, especially those in healthharming commodity industries, poses a major threat to efforts to protect and promote population health. Accordingly, it is critical that the public health community focuses on understanding, identifying, tracking, and addressing corporate power.

Corporate market power is a vital power concept that warrants more public health attention as part of a broader corporate power research agenda. We argue that market power can be broadly understood as playing a central role in perpetuating corporate power through the shaping of market environments as a means of ensuring the ongoing accumulation of substantial profits. Empirically, the SCP model described in this paper could act as a useful starting point to examine corporate market power from a public health point of view, as well as to engage with the policy, regulatory and institutional levers designed, at least in principle, to curb the concentrated market power of firms that generate profit at the expense of population health. 


\section{Supplementary Information}

The online version contains supplementary material available at https://doi. org/10.1186/s12992-021-00688-2

Additional file 1: Supplementary file 1. Definition of the ultraprocessed food (UPF) industry

Additional file 2: Supplementary file 2. A number of key structure and performance-related metrics to examine the market power from a public health perspective

Additional file 3: Supplementary file 3. A brief description of Porter's five forces framework

\section{Acknowledgements}

The authors would like to acknowledge Dr. Ching-Jen Sun, Associate Professor in the Faculty of Business and Law at Deakin University, who assisted in collecting and analysing the Industrial Organization related literature. Gary Sacks is supported by a Heart Foundation Future Leader Fellowship (102035) from the National Heart Foundation of Australia. He is also a researcher within National Health and Medical Research Council (NHMRC) Centres for Research Excellence entitled Reducing Salt Intake Using Food Policy Interventions (APP1117300) and a Centre of Research Excellence in Food Retail Environments for Health (RE-FRESH) (APP1152968) (Australia). He has also received other funding from the NHMRC, Australian Research Council (ARC), Canadian Institutes of Health Research (CIHR) and the World Health Organization (WHO).

\section{Authors' contributions}

B.W., G.S., O.W., and P.B. contributed to the study design. B.W. collected, analysed and interpreted the literature. V.N. and O.W. contributed to analysing and interpreting the competition policy, Industrial Organization and global political economy related literature. B.W. drafted the manuscript G.S., O.W., P.B. and V.N. reviewed, edited, and helped to finalise the manuscript for submission. All authors read and approved the final manuscript.

\section{Funding}

Benjamin Wood is a recipient of a Deakin University Postgraduate Research Scholarship funded by the Institute for Health Transformation, Deakin University, Australia. The funding body had no role in the design of the study, the collection, analysis and interpretation of the data, and in writing the manuscript.

\section{Availability of data and materials}

Not applicable.

\section{Declarations}

Ethics approval and consent to participate

Not applicable.

\section{Consent for publication}

Not applicable.

\section{Competing interests}

The authors declare they have no competing interests.

\section{Author details}

${ }^{1}$ Global Obesity Centre, Deakin University, Geelong, Australia. ${ }^{2}$ School of Political Science and International Studies, University of Leeds, Leeds, UK. ${ }^{3}$ Institute for Physical Activity and Nutrition, Deakin University, Geelong, Australia. ${ }^{4}$ Macquarie Law School, Macquarie University, Sydney, Australia.

Received: 22 June 2020 Accepted: 18 March 2021

Published online: 06 April 2021

\section{References}

1. Slade J. The tobacco epidemic: lessons from history. J Psychoactive Drugs. 1989;21(3):281-91. https://doi.org/10.1080/02791072.1989.10472169.
2. Moodie R, Stuckler D, Monteiro C, Sheron N, Neal B, Thamarangsi T, et al. Profits and pandemics: prevention of harmful effects of tobacco, alcohol, and ultra-processed food and drink industries. Lancet. 2013;381(9867):670-9. https://doi.org/10.1016/S0140-6736(12)62089-3.

3. Brownell K, Warner K. The perils of ignoring history: big tobacco played dirty and millions died. How similar is big food? Millbank Quart. 2009;87(1): 259-94. https://doi.org/10.1111/j.1468-0009.2009.00555.x.

4. Nestle M. Food politics: how the food industry influences nutrition and health. Berkeley: University of California Press; 2007. https://doi.org/10.1525/ 9780520934467

5. Nestle M. Soda politics : taking on big soda (and winning). Oxford: Oxford University Press; 2015. xii, 508 pages p.

6. Kickbusch I, Allen L, Franz C. The commercial determinants of health. Lancet Glob Health. 2016;4(12):e895-e6. https://doi.org/10.1016/S2214-109X(16)30217-0.

7. Millar J. The corporate determinants of health: how big business affects our health, and the need for government action! Can J Pub Health. 2013;104(4): 327-9.

8. McKee M, Stuckler D. Revisiting the corporate and commercial determinants of health. Am J Public Health. 2018;108(9):1167-70. https://doi.org/10.2105/A JPH.2018.304510.

9. Madureira Lima J, Galea S. Corporate practices and health: a framework and mechanisms. Global Health. 2018;14(21).

10. Holden C, Lee K. Corporate power and social policy: the political economy of the transnational tobacco companies. Glob Soc Policy. 2009;9(3):328-54 https://doi.org/10.1177/1468018109343638.

11. Wood B, Baker P, Sacks G. Conceptualising the commercial determinants of health using a power lens: a review and synthesis of existing frameworks. Int J Health Policy Manag. 2021:1-11.

12. Lacy-Nichols J, Marten R. Power and the commercial determinants of health: ideas for a research agenda. BMJ Glob Health. 2021;6:2.

13. Madureira Lima J, Galea S. The corporate permeation index - a tool to study the macrosocial determinants of non-communicable disease. SSM Population Health. 2019:100361.

14. Gore R, Parker R. Analysing power and politics in health policies and systems. Glob Public Health. 2019;14(4):481-8. https://doi.org/10.1080/17441 692.2019 .1575446

15. Nitzan J, Bichler S. Capital as power: a study of order and creorder: Routledge; 2009. https://doi.org/10.4324/9780203876329.

16. Navarro V. Neoliberalism, globalization, and inequalities : consequences for health and quality of life. Amityville: Baywood; 2007. vii, 506 p. p.

17. Mikler J. National Instiutional Embeddedness. The political power of global corporations. Cambridge: Polity Press; 2018.

18. Biely K, Maes D, Van Passel S. Market Power Extended: From Foucault to Meadows. Sustainability. 2018;10:8.

19. Stiglitz J. Towards a broader view of competition policy. Competition Policy for the New Era: Insights from the BRICS Countries. 2017.

20. Elzinga K, Mills D. The Lerner Index of Monopoly Power: Origins and Uses. Am Econ Rev. 2011;101:3.

21. Fuchs D, Glaab K. Material power or normative conflict: determinants of the interaction between global and local agrifood governance. In: Münster U, editor. Münster. 2010.

22. Fuchs D, Di Giulio A, Glaab K, Lorek S, Maniates M, Princen T, et al. Power: the missing element in sustainable consumption and absolute reductions research and action. J Clean Prod. 2016;132:298-307. https://doi.org/10.101 6/j.jclepro.2015.02.006

23. Sexton RJ. Market power, misconceptions, and modern agricultural markets. Am J Agric Econ. 2012;95(2):209-19.

24. Hawkins B, Holden C, Eckhardt J, Lee K. Reassessing policy paradigms: a comparison of the global tobacco and alcohol industries. Glob Public Health. 2018;13(1):1-19. https://doi.org/10.1080/17441692.2016.1161815.

25. Fuchs D. Commanding Heights? The Strength and Fragility of Business Power in Global Politics. London: Millenium Annual Conference on Facets of Power in International Relations; 30-31 October; 2005. p. 39.

26. Fuchs D. Exploring the role of business in global governance. Business power in global governance. Boulder: Lynne Rienner; 2007

27. Mialon M. An overview of the commercial determinants of health. Glob Health. 2020;16(1):74. https://doi.org/10.1186/s12992-020-00607-x.

28. Finch D, Briggs A, Tallack C. Improving health by tackling market failure. UK: The Health Foundation; 2020.

29. Stigler G. The theory of economic regulation. Bell J Econ Manag Sci. 1971; 2(1):3-21. https://doi.org/10.2307/3003160. 
30. Stucke M. Reconsidering Antitrust's Goals. Boston College Law Review. 2012; 53(4).

31. Wu T. After consumer welfare, now what? The "protection of competition" standard in practice. In: School CL, editor. Columbia Public Law School Research Paper. 2018.

32. Swinburn BA, Kraak VI, Allender S, Atkins VJ, Baker PI, Bogard JR, et al. The global syndemic of obesity, undernutrition, and climate change: the lancet commission report. Lancet. 2019;393(10173):791-846. https://doi.org/10.101 6/S0140-6736(18)32822-8

33. Nestle M. Food politics : how the food industry influences nutrition and health. Berkeley: University of California Press; 2002. xii, 457 p. p.

34. PLoS Medicine Editors. PLoS Medicine series on Big Food: the food industry is ripe for scrutiny. PLoS Med. 2012;9(6):e1001246.

35. Monteiro CA, Levy RB, Claro RM, de Castro IR, Cannon G. Increasing consumption of ultra-processed foods and likely impact on human health: evidence from Brazil. Public Health Nutr. 2011;14(1):5-13. https://doi.org/10.1 017/S1368980010003241.

36. Monteiro CA, Moubarac JC, Cannon G, Ng SW, Popkin B. Ultra-processed products are becoming dominant in the global food system. Obes Rev. 2013;14(Suppl 2):21-8. https://doi.org/10.1111/obr.12107.

37. Srour B, Fezeu LK, Kesse-Guyot E, Allès B, Méjean C, Andrianasolo RM, et al. Ultra-processed food intake and risk of cardiovascular disease: prospective cohort study (NutriNet-Santé). BMJ. 2019:11451. https://doi.org/10.1136/bmj. 11451 .

38. Rico-Campà A, Martínez-González MA, Alvarez-Alvarez I, Mendonça RdD, de la Fuente-Arrillaga C, Gómez-Donoso C, et al. Association between consumption of ultra-processed foods and all cause mortality: SUN prospective cohort study. Bmj. 2019.

39. Baker P, Machado P, Santos T, Sievert K, Backholer K, Hadjikakou M, et al. Ultra-processed foods and the nutrition transition: global, regional and national trends, food systems transformations and political economy drivers. Obes Rev. 2020;21(12):e13126. https://doi.org/10.1111/obr.13126.

40. Louzada M, Ricardo CZ, Steele EM, Levy RB, Cannon G, Monteiro CA. The share of ultra-processed foods determines the overall nutritional quality of diets in Brazil. Public Health Nutr. 2018;21(1):94-102. https://doi.org/10.1017/ S1368980017001434

41. Machado PP, Steele EM, Levy RB, Sui Z, Rangan A, Woods J, et al. Ultraprocessed foods and recommended intake levels of nutrients linked to noncommunicable diseases in Australia: evidence from a nationally representative cross-sectional study. BMJ Open. 2019;9(8):e029544. https:// doi.org/10.1136/bmjopen-2019-029544.

42. Rauber F, da Costa Louzada ML, Steele EM, Millett C, Monteiro CA, Levy RB. Ultra-Processed Food Consumption and Chronic Non-Communicable Diseases-Related Dietary Nutrient Profile in the UK (2008(-)2014). Nutrients. 2018;10:5.

43. Blanco-Rojo R, Sandoval-Insausti H, Lopez-Garcia E, Graciani A, Ordovas JM, Banegas JR, et al. Consumption of ultra-processed foods and mortality: a National Prospective Cohort in Spain. Mayo Clin Proc. 2019;94(11):2178-88. https://doi.org/10.1016/.jmayocp.2019.03.035

44. Pagliai G, Dinu M, Madarena MP, Bonaccio M, lacoviello L, Sofi F. Consumption of ultra-processed foods and health status: a systematic review and meta-analysis. Br J Nutr. 2020:1-11.

45. Chen X, Zhang Z, Yang H, Qiu P, Wang H, Wang F, et al. Consumption of ultraprocessed foods and health outcomes: a systematic review of epidemiological studies. Nutr J. 2020;19(1):86. https://doi.org/10.1186/s12937-020-00604-1.

46. Elizabeth L, Machado P, Zinocker M, Baker P, Lawrence M. Ultra-Processed Foods and Health Outcomes: A Narrative Review. Nutrients. 2020;12:7.

47. Lane MM, Davis JA, Beattie S, et al. Ultraprocessed food and chronic noncommunicable diseases: A systematic review and meta-analysis of 43 observational studies. Obes Rev. 2021;22(3):e13146. https://doi.org/10.1111/ obr.13146.

48. Nardocci M, Leclerc BS, Louzada ML, Monteiro CA, Batal M, Moubarac JC. Consumption of ultra-processed foods and obesity in Canada. Can J Public Health. 2019;110(1):4-14. https://doi.org/10.17269/s41997-018-0130-x.

49. Canhada SL, Luft VC, Giatti L, Duncan BB, Chor D, Fonseca M, et al. Ultraprocessed foods, incident overweight and obesity, and longitudinal changes in weight and waist circumference: the Brazilian longitudinal study of adult health (ELSA-Brasil). Public Health Nutr. 2020;23(6):1076-86. https:// doi.org/10.1017/S1368980019002854.

50. Srour B, Fezeu LK, Kesse-Guyot E, et al. Ultraprocessed Food Consumption and Risk of Type 2 Diabetes Among Participants of the NutriNet-Santé
Prospective Cohort. JAMA Intern Med. 2020;180(2):283-91. https://doi.org/1 0.1001/jamainternmed.2019.5942.

51. Martinez Steele E, Juul F, Neri D, Rauber F, Monteiro CA. Dietary share of ultra-processed foods and metabolic syndrome in the US adult population. Prev Med. 2019;125:40-8. https://doi.org/10.1016/j.ypmed.2019.05.004.

52. Fiolet T, Srour B, Sellem L, Kesse-Guyot E, Alles B, Mejean C, et al. Consumption of ultra-processed foods and cancer risk: results from NutriNet-Sante prospective cohort. BMJ. 2018;360:k322.

53. Melo B, Rezende L, Machado P, Gouveia N, Levy R. Associations of ultraprocessed food and drink products with asthma and wheezing among Brazilian adolescents. Pediatr Allergy Immunol. 2018;29(5):504-11. https:// doi.org/10.1111/pai.12911.

54. Julia C, Martinez L, Alles B, Touvier M, Hercberg S, Mejean C, et al. Contribution of ultra-processed foods in the diet of adults from the French NutriNet-Sante study. Public Health Nutr. 2018;21(1):27-37. https://doi.org/1 $0.1017 /$ S1368980017001367.

55. Gómez-Donoso C, Sánchez-Villegas A, Martínez-González MA, Gea A, de Deus MR, Lahortiga-Ramos F, et al. Ultra-processed food consumption and the incidence of depression in a Mediterranean cohort: the SUN project. Eur J Nutr. 2020;59(3):1093-103. https://doi.org/10.1007/s00394-019-01970-1.

56. Baker P, Friel S. Food systems transformations, ultra-processed food markets and the nutrition transition in Asia. Glob Health. 2016;12(1):80. https://doi. org/10.1186/s12992-016-0223-3.

57. Food \& Water Watch. Grocery Goliaths: How Food Monopolies Impact Consumers. Food \& Water Watch; 2013.

58. Carlton DW, Perloff JM. Modern industrial organization. 3rd ed. Boston: Addison Weasley; 2000.

59. Bain JS. Barriers to new competition. Cambridge: Harvard University Press; 1956. https://doi.org/10.4159/harvard.9780674188037.

60. Bain JS. Industrial organization. New York: Wiley; 1968.

61. Hovenkamp H. Antitrust after Populism. In: Crane DA, Hovenkamp H, editors. The making of competition policy: Legal and Economic Sources: Oxford University Press; 2013. https://doi.org/10.1093/acprof:osobl/97801 99782796.003.0007.

62. Crane DA. Structuralism. In: Crane DA, Hovenkamp H, editors. The Making of Competition Policy: Legal and Economic Sources: Oxford University Press; 2013. p. 318-89.

63. Tirole J. The theory of industrial organization. Cambridge: Massachusetts London, England: The MIT Press; 1988.

64. Sawyer LP. US Antitrust Law and Policy in Historical Perspective. Harvard Business School. 2019. p. 35

65. Lee C. SCP, NEIO and beyond. In: School NUB, Campus UoNM, editors. 2007.

66. Bresnahan T. Empirical studies of industries with market power. Handbook Indust Org. 1989;2:110-57.

67. Corones S. Competition policy review : draft recommendations on competition laws. Aust Bus Law Rev. 2014;42(6):479-86.

68. Australian Competition and Consumer Commission. Guidelines on misuse of market power. ACCC: Canberra; 2018.

69. Australian Competition and Consumer Commission. Guidelines for authorisation of conduct (non-merger). ACCC: Canberra; 2019.

70. OECD. Oligopoly markets: Organisation for Economic Co-operation and Development; 2015 [Available from: https:/www.oecd.org/daf/competition/ oligopoly-markets.html

71. OECD Committee on Competition Law and Policy. Oligopoly. Paris: OECD 1999. Contract No.: DAFFE/CLP (99)25.

72. OECD. Market Concentration. Organisation for Economic Co-operation and Development; 2018. Contract No.: DAF/COMP/WD(2018)46.

73. Abdela A. Market Concentration and the importance of properly defined markets. In: Institute R, editor. Corporate Power 2018.

74. Naldi M, Flamini M. The CR4 index and the interval estimation of the Herfindahl-Hirschman index: an empirical comparison. HAL. 2014.

75. Weinstock DS. Using the Herfindahl index to measure concentration. Antitrust Bull. 1982:285-301.

76. Cavalleri ME, Alice McAdam, Peter Petroulakis, Filippos Soares, Ana Vansteenkiste Isabel. Concentration, market power and dynamism in the euro area. European Central Bank; 2019. Contract No.: 2253.

77. Justice TUSDo. Horinzontal Merger Guidelines 1997 [Available from: https:// www.justice.gov/atr/horizontal-merger-guidelines-0.

78. Arnold R. Economics: Thomson South-Western; 2008.

79. Elliott M, Galeotti A. The role of networks in antitrust investigations. Oxf Rev Econ Policy. 2019;35(4):614-37. https://doi.org/10.1093/oxrep/grz022. 
80. International Competition Network. Market Definition. 2018. Available from: https://www.internationalcompetitionnetwork.org/training/marketdefinition/. Accessed 5 Feb 2020.

81. OECD. Industry - SNA. 2013. Available from: https://stats.oecd.org/glossary/ detail.asp?ID=1341. Accessed 24 Apr 2020.

82. Australian Competition and Consumer Commission. Merger Guidelines. ACCC: Canberra; 2017.

83. Harvey D. Monopoly and competition: centralisation and decentralisation. Seventeen Contradictions and The End of Capitalism: Oxford University Press; 2014.

84. OECD. Common Ownership by Institutional Investors and Its Impact on Competition. Paris: Organisation for Economic Co-operation and Development; 2017. Contract No.: DAF/COMP (2017)10.

85. Clapp J. The rise of financial investment and common ownership in global agrifood firms. Rev Int Polit Econ. 2019;26(4):604-29. https://doi.org/10.1080/ 09692290.2019.1597755.

86. Posner E, Scott Morton F, Weyl G. A proposal to limit the anti-competitive power of institutional investors. Corporate Governance and Economics eJournal 2017.

87. Elhauge E. Horizontal Shareholding Harvard Law Review 2016;129.

88. Azar JS, Martin Tecu, Isabel. Anticompetitive Effects of Common Ownership. Journal of Finance. 2018;73(4).

89. Lambert TA, Sykuta ME. The case for doing nothing about institutional investors' common ownership of small stakes in competing firms. Virginia Law Bus Rev. 2019:13.

90. OECD. Competition and Barriers to Entry 2007 [23 July 2019]. Available from: https://www.oecd.org/competition/mergers/37921908.pdf.

91. Interbrand. Best Global Brands 2019 Rankings: Interbrand; 2020 [Available from: https://www.interbrand.com/best-brands/best-global-brands/2019/ra nking/.

92. Salvo A. Cut-throat fringe competition in an emerging country market: tax evasion or the absence of market power? J Ind Econ. 2009;57(4):677-711. https://doi.org/10.1111/j.1467-6451.2009.00400.x.

93. Herath D. Impediments to the ability of Canadian food-processing firms to compete: evidence from a survey on innovation. Agribusiness. 2014;30(3): 244-64. https://doi.org/10.1002/agr.21361.

94. Moss DL, Taylor CR. Short ends of the stick: The plight of growers and consumers in concentrated agricultural supply chains. Wis. L. Rev. 2014:337.

95. United States Department of Agriculture. New Directions in Global Food Markets. USDA: 2005. Contract No.: Agriculture Information Bulletin Number 794.

96. Pritchard B. The transnational corporate networks of breakfast cereals in Asia. Environ Plan A. 2000;32(5):789-804. https://doi.org/10.1068/a32113.

97. Hayes A. Brand Equity: Investopedia; 2019 [Available from: https://www. investopedia.com/terms/b/brandequity.asp.

98. OECD Competition Committee. Competition Issues in the Food Chain Industry. OECD, ; 2014. Contract No.: DAF/COMP (2014)16.

99. Wood B, Williams O, Nagarajan V, Sacks G. Market strategies used by processed manufacturers to increase and consolidate their power: A systematic review and document analysis. Glob Health. 2021:17.

100. OECD. STAN indicators: collection of calculation formula. The Organisation for Economic Co-operation and Development; 2011.

101. Pritchard B. In: Uo S, editor. The tangible and intangible spaces of agro-food capital. Rio de Janeiro: International rural sociology association world congress $X ; 2000$.

102. Pritchard B. Geographies of the firm and transnational agro-food corporations in East Asia. Singap J Trop Geogr. 2000;21(3):246-62. https:// doi.org/10.1111/1467-9493.00080.

103. Sikka $P$, Willmott $H$. The dark side of transfer pricing: its role in tax avoidance and wealth relativeness. Essex: Centre for Global Accountability UoE; 2010.

104. Burch D, Lawrence G. Towards a third food regime: behind the transformation. Agric Hum Values. 2009;26(4):267-79. https://doi.org/10.1 007/s10460-009-9219-4.

105. Vaitsos C. Patents re-visited: their function in developing countries. J Dev Stud. 1972;9(1):71-97. https://doi.org/10.1080/00220387208421432.

106. McClure H. US IRS prevails in Coca-Cola transfer pricing dispute over intercompany royalties New York City: Multinational Group Tax \& Transfer Pricing News; 2020 [Available from: https://mnetax.com/us-irs-prevails-incoca-cola-transfer-pricing-dispute-over-intercompany-royalties-41461

107. Baron D. Integrated strategy: market and nonmarket components. Calif Manag Rev. 1995;37(2):47-65. https://doi.org/10.2307/41165788.
108. Porter ME. Competitive strategy: techniques for analyzing industries and companies. New York: Free Press; 1980

109. Porter ME. The five competitive forces that shape strategy. Harv Bus Rev. 2008:23-41.

110. Barney JB, Mackey A. Monopoly profits, efficiency profits, and teaching strategic management. Acad Manag Learn Educ. 2018;17(3):359-73. https:// doi.org/10.5465/amle.2017.0171.

111. Sammut-Bonnici T, Galea D. PEST Analysis, Chapter Published in: Wiley Encyclopedia of Management. Hoboken: Wiley; 2015:12.

112. Baysinger BD. Domain Maintenance as an Objective of Business Political Activity: An Expanded Typology. Acad Manag Rev. 1984;9:2.

113. Savell $E$, Gilmore $A B$, Fooks $G$. How does the tobacco industry attempt to influence marketing regulations? A systematic review. PLoS One. 2014;9(2): e87389. https://doi.org/10.1371/journal.pone.0087389.

114. Mialon M, Swinburn B, Sacks G. A proposed approach to systematically identify and monitor the corporate political activity of the food industry with respect to public health using publicly available information. Obes Rev. 2015;16(7):519-30. https://doi.org/10.1111/obr.12289.

115. Levy D, Egan D. A Neo-Gramscian Approach to Corporate Political Activity: Conflict and Accommodation in the Climate Change Negotiations. J Manag Stud. 2003:40:4.

116. Levy DN, Peter. Business strategy and international environmental governance: toward a neo-Gramscian synthesis. Glob Environ Politics. 2002; 2(4):84-101. https://doi.org/10.1162/152638002320980632.

117. Baker P, Santos T, Neves PA, Machado P, Smith J, Piwoz E, et al. First-food systems transformations and the ultra-processing of infant and young child diets: The determinants, dynamics and consequences of the global rise in commercial milk formula consumption. Matern Child Nutr. 2020:e13097.

118. Applbaum K. Getting to yes: corporate power and the creation of a psychopharmaceutical blockbuster. Cult Med Psychiatry. 2009;33(2):185-215. https://doi.org/10.1007/s11013-009-9129-3.

119. Herrick C. Shifting blame/selling health: corporate social responsibility in the age of obesity. Sociol Health IIIn. 2009;31(1):51-65. https://doi.org/10.1111/ j.1467-9566.2008.01121.x.

120. Fair Trade Advocacy Office. EU competition law and sustainability in food systems: addressing the broken links. Brussels; 2019.

121. OECD. The Role of Efficiency Claims in Antitrust Proceedings. Organisation for Economic Co-operation and Development; 2012. Contract No.: DAF/ COMP (2012)23

122. Stiglitz J. The price of inequality: how today's divided society endangers our future. New York: W.W. Norton \& Co.; 2012.

123. Wilson C. Welfare Standards Underlying Antitrust Enforcement: What You Measure is What You Get. In: Commissioner USFTC, editor. In: Luncheon Keynote Address at George Mason Law Review 22nd Antitrust Symposium. Arlington: Antitrust at the Crossroads? 2019.

124. Crane DA. The tempting of antitrust: Robert Bork and the goals of antitrust policy. Antitrust Law J. 2014;79(3):835-53.

125. Deans G, Kroeger F, Zeisel S. The Consolidation Curve: Harvard Business Review; 2002 [12 June 2019]. Available from: https://hbr.org/2002/12/theconsolidation-curve.

126. Bork R. The antitrust paradox: a policy at war with itself. New York: Basic Books; 1978.

127. Wardle J, Baranovic M. Is lack of retail competition in the grocery sector a public health issue? Aust N Z J Public Health. 2009;33(5):477-81. https://doi. org/10.1111/j.1753-6405.2009.00433.x

128. Clapp J. Mega-mergers on the menu: corporate concentration and the politics of sustainability in the global food system. Glob Environ Politics. 2018;18(2):12-33. https://doi.org/10.1162/glep_a_00454.

129. Bogus $C$. The new road to serfdom: the curse of bigness and the failure of antitrust. Univ Michigan J Law Reform. 2015:49.

130. Stiglitz J. Government failure vs. market failure: Principles of regulation In: University C, editor. 2009.

131. Hantke-Domas M. The public interest theory of regulation: non-existence or misinterpretation? Eur J Law Econ. 2003;15(2):165-94. https://doi.org/10.1 023/A:1021814416688

132. Howard PH. In: Gooman DG, Michael, editors. Concentration and Power in the Food System: Who Controls What We Eat? New York: Bloomsbury; 2016.

133. Hayes A. Earnings Before Interest, Taxes, Depreciation and Amortization EBITDA: Investopedia; 2020 [Available from: https://www.investopedia.com/ terms/e/ebitda.asp. 
134. Eilon S. Key ratios for corporate performance. Omega. 1992;20(3):337-43. https://doi.org/10.1016/0305-0483(92)90038-9.

135. Bork RH, Sidak JG. The misuse of profit margins to infer market power. J Compet Law Econ. 2013;9(3):511-30. https://doi.org/10.1093/joclec/nht024.

136. OECD. New sources of growth: intangible assets. Paris: Organisation for Economic Co-operation and Development; 2011.

137. Aguiar de Medeiros C, Trebat N. Inequality and income distribution in global value chains. J Econ Issues. 2017;51 (2):401-8. https://doi.org/10.1080/ 00213624.2017 .1320916$.

138. Sell SK. 21st-century capitalism: structural challenges for universal health care. Glob Health. 2019;15(Suppl 1):76. https://doi.org/10.1186/s12992-0190517-3.

139. Vuong B. Industry report C1191: snack food manufacturing in Australia. IBISWorld; 2019

140. Vuong B. Industry report C1182: chocolate and confectionery manufacturing in Australia. IBISWorld; 2019.

141. Yeoh YH. Industry report C1211A: soft drink manufacturing in Australia. IBISWorld 2019.

142. Shamir R. The age of responsibilization: on market-embedded morality. Econ Soc. 2008;37(1):1-19.

143. Stuckler D, McKee M, Ebrahim S, Basu S. Manufacturing epidemics: the role of global producers in increased consumption of unhealthy commodities including processed foods, alcohol, and tobacco. PLoS Med. 2012;9(6): e1001235. https://doi.org/10.1371/journal.pmed.1001235.

144. Schmidt L, Mialon M, Kearns C, Crosbie E. Transnational corporations, obesity and planetary health. Lancet Planetary Health. 2020;4(7):e266-e7. https://doi.org/10.1016/S2542-5196(20)30146-7.

145. Beaumont NJ, Aanesen M, Austen MC, Borger T, Clark JR, Cole M, et al. Global ecological, social and economic impacts of marine plastic. Mar Pollut Bull. 2019;142:189-95. https://doi.org/10.1016/j.marpolbul.2019.03.022.

146. Tearfund. No Time To Waste: Tackling the plastic pollution crisis before it's too late. Teddington: Tearfund; 2019.

147. Tearfund. The burning question: Will companies reduce their plastic use? ; 2020.

148. Miller D, Harkins C. Corporate strategy, corporate capture: food and alcohol industry lobbying and public health. Crit Soc Policy. 2010;30(4):564-89. https://doi.org/10.1177/0261018310376805.

149. Milsom P, Smith R, Baker P, Walls H. Corporate power and the international trade regime preventing progressive policy action on non-communicable diseases: a realist review. Health Policy Plan. 2020. https:/doi.org/10.1093/ heapol/czaa148.

150. Daly H. Allocation, distribution, and scale: towards an economics that is efficient, just, and sustainable. Ecol Econ. 1992;6(3):185-93. https://doi.org/1 0.1016/0921-8009(92)90024-M.

151. Han E, Powell LM. Consumption patterns of sugar-sweetened beverages in the United States. J Acad Nutr Diet. 2013;113(1):43-53. https://doi.org/10.101 6/j.jand.2012.09.016.

152. Pechey R, Jebb SA, Kelly MP, Almiron-Roig E, Conde S, Nakamura R, et al. Socioeconomic differences in purchases of more vs. less healthy foods and beverages: analysis of over 25,000 British households in 2010. Soc Sci Med. 2013;92:22-6. https://doi.org/10.1016/j.socscimed.2013.05.012.

153. van Ansem WJ, van Lenthe FJ, Schrijvers $C T$, Rodenburg G, van de Mheen D. Socioeconomic inequalities in children's snack consumption and sugar-sweetened beverage consumption: the contribution of home environmental factors. Br I Nutr. 2014;112(3):467-76. https://doi.org/10.1017/S0007114514001007.

154. Backholer K, Blake M, Vandevijvere S. Sugar-sweetened beverage taxation: an update on the year that was 2017. Public Health Nutr. 2017;20(18):321924. https://doi.org/10.1017/S1368980017003329.

155. Paraje G. The effect of Price and socio-economic level on the consumption of sugar-sweetened beverages (SSB): the case of Ecuador. PLoS One. 2016; 11(3):e0152260. https://doi.org/10.1371/journal.pone.0152260.

156. Bolt-Evensen K, Vik FN, Stea TH, Klepp KI, Bere E. Consumption of sugarsweetened beverages and artificially sweetened beverages from childhood to adulthood in relation to socioeconomic status - 15 years follow-up in Norway. Int J Behav Nutr Phys Act. 2018;15(1):8. https://doi.org/10.1186/s12 966-018-0646-8.

157. Miller C, Ettridge K, Wakefield M, Pettigrew S, Coveney J, Roder D, et al. Consumption of Sugar-Sweetened Beverages, Juice, ArtificiallySweetened Soda and Bottled Water: An Australian Population Study. Nutrients. 2020;12:3.
158. Singh GM, Micha R, Khatibzadeh S, Lim S, Ezzati M, Mozaffarian D, et al. Estimated global, regional, and National Disease Burdens Related to sugarsweetened beverage consumption in 2010. Circulation. 2015;132(8):639-66. https://doi.org/10.1161/CIRCULATIONAHA.114.010636.

159. Agardh E, Allebeck P, Hallqvist J, Moradi T, Sidorchuk A. Type 2 diabetes incidence and socio-economic position: a systematic review and metaanalysis. Int J Epidemiol. 2011;40(3):804-18. https://doi.org/10.1093/ije/ dyr029.

160. Newton S, Braithwaite D, Akinyemiju TF. Socio-economic status over the life course and obesity: systematic review and meta-analysis. PLoS One. 2017; 12(5):e0177151. https://doi.org/10.1371/journal.pone.0177151.

161. Ireland P. Shareholder primacy and the distribution of wealth. Mod Law Rev 2005;68(1):49-81. https://doi.org/10.1111/j.1468-2230.2005.00528.x.

162. Gebeloff R. Who Owns Stocks? Explaining the Rise in Inequality During the Pandemic: The New York Times; 2021 [Available from: https:/www.nytimes. com/2021/01/26/upshot/stocks-pandemic-inequality.html.

163. Hager SB, Baines J. The tax advantage of big business: how the structure of corporate taxation fuels concentration and inequality. Polit Soc. 2020;48(2): 275-305. https://doi.org/10.1177/0032329220911778.

164. Lazonick W. The quest for shareholder value: stock repurchases in the US economy. Louvain Econ Rev. 2008;74:479-540.

165. Lazonick W, Sakinç M, Hopkins M. Why Stock Buybacks Are Dangerous for the Economy: Harvard Business Review; 2020 [Available from: https://hbr. org/2020/01/why-stock-buybacks-are-dangerous-for-the-economy\#: :text= When\%20companies\%20do\%20these\%20buybacks,2017\%2C\%20a ccording\%20to\%20JPMorgan\%20Chase.

166. OECD. Dynamic efficiencies in merger analysis. Paris: Organisation for Economic Co-operation and Development; 2007.

167. Syrneonidis G. Innovation, firm size and market structure: Schumpeterian hypothesis and some new themes. OECD Econ Stud. 1996:27.

168. Baker J. Beyond Schumpeter vs. Arrow: How Antitrust Fosters Innovation. Am Univ Washington Coll Law. 2007:74.

169. Scrinis G. Reformulation, fortification and functionalization: big food corporations' nutritional engineering and marketing strategies. J Peasant Stud. 2015;43(1):17-37.

170. Subramanian S. Is fair trade finished? Fairtrade changed the way we shop. But major companies have started to abandon it and set up their own inhouse imitations - threatening the very idea of fair trade. . The Guardian. 2019

171. Raworth K. Why it's time for doughnut economics. IPPR Progressive Rev. 2017;24(3):216-22. https://doi.org/10.1111/newe.12058.

172. Rosenbloom D, Markard J, Geels FW, Fuenfschilling L. Opinion: why carbon pricing is not sufficient to mitigate climate change-and how "sustainability transition policy" can help. Proc Natl Acad Sci U S A. 2020;117(16):8664-8. https://doi.org/10.1073/pnas.2004093117.

173. Rockström J, Steffen W, Noone K, Persson Å, Chapin FS, Lambin EF, et al. A safe operating space for humanity. Nature. 2009;461(7263):472-5. https:// doi.org/10.1038/461472a.

174. War on Want. Coca-Cola: drinking the world dry. London: War on Want; 2007 Available from: https://waronwant.org/news-analysis/coca-coladrinking-world-dry.

175. WFP Solidarity Collective. Coca-Cola's new bottling plant threatens workers' rights in Colombia Minneapolis, USA. 2015. Available from: https://www. solidaritycollective.org/post/coca-cola-s-new-bottling-plant-threatensworkers-rights-in-colombia.

176. Friel S. Redressing the corporate cultivation of consumption: releasing the weapons of the structurally weak. Int J Health Policy Manag. 2020. https:// doi.org/10.34172/ijhpm.2020.205.

177. Mikler J. Theorizing global corporations' power. The political power of global corporations. Cambridge: Polity Press; 2018.

178. Glick M. The unsound theory behind the consumer (and Total) welfare goal in antitrust. Roosevelt Institute; 2018.

179. Crane DA. Ordoliberalism and the Freiburg School. The Making of Competition Policy: Legal and Economic Sources: Oxford Scholarship Online; 2013. p. 252

180. Khan L. The new Brandeis movement: America's antimonopoly debate. J Eur Compet Law Pract. 2018;9(3):131-2. https://doi.org/10.1093/jeclap/lpy020.

181. Fox E. Competition policy: the comparative advantage of developing countries. In: School of Law NYU, editor. Law \& Economics Research Paper Series. 2017. 
182. Tucker T. Industrial policy and planning: what it is and how to do it better Roosevelt Institute; 2019

183. IPES-Food. Towards a Common Food Policy for the European Union. International Panel of Experts on Sustainable Food Systems; 2019.

184. Parsons K, Hawkes C. Connecting food systems for co-benefits: how can food systems combine diet-related health with environmental and economic policy goals? Copenhagen: WHO Regional Office for Europe; 2018.

185. Pingali P. Agricultural policy and nutrition outcomes - getting beyond the preoccupation with staple grains. Food Secu. 2015;7(3):583-91. https://doi. org/10.1007/s12571-015-0461-x.

186. Swinburn B, Sacks G, Vandevijvere S, Kumanyika S, Lobstein T, Neal B, et al. INFORMAS (international network for food and obesity/non-communicable diseases research, monitoring and action support): overview and key principles. Obes Rev. 2013;14(Suppl 1):1-12. https://doi.org/10.1111/obr.12 087.

\section{Publisher's Note}

Springer Nature remains neutral with regard to jurisdictional claims in published maps and institutional affiliations.

Ready to submit your research? Choose BMC and benefit from:

- fast, convenient online submission

- thorough peer review by experienced researchers in your field

- rapid publication on acceptance

- support for research data, including large and complex data types

- gold Open Access which fosters wider collaboration and increased citations

- maximum visibility for your research: over $100 \mathrm{M}$ website views per year

At BMC, research is always in progress.

Learn more biomedcentral.com/submissions 